\title{
韓国安東河回村と岐阜県大野郡白川村荻町にみる 歴史的景観の管理に関する比較研究
}

\section{A Comparative Study on the Historic Landscape Management of Andong Hahoe Village and Shirakawa Ogimachi Village}

\author{
孫＼cjkstart鏞勳* 黒田 乃生* 下村 彰男* \\ Yonghoon SON Nobu KURODA Akio SHIMOMURA
}

\begin{abstract}
Over the past few decades, the concern with management of historic landscape has been growing. This paper is a comparative study about management of historic landscape in both of Korean and Japanese traditional villages. The purpose of this study is to clear up the management style of historic landscape in two countries based on the Cultural Properties Protection Act. The subjects of this study are Andong hahoe village in Korea and Shirakawa ogimachi village in Japan. As the result of comparative study, characters of Historic landscape management in two villages are figured out. The management of the historic landscape of Andong Hahoe village is characterized as restriction for preservation from the total village to single element. On the other hand, the management of the historic landscape of Shirakawa ogimachi village is characterized as mediation for combination of historic buildings with places of involvement. On the basis of the result, this paper discusses the problems related to the historic landscape managements of two villages.
\end{abstract}

Keywords: the Cultural Properties Protection Act, Historic landscape management, Andong Hahoe village, Shirakawa Ogimachi village, Comparative studies of Korea and Japan

キーワード：文化財保護法，歴史的景観管理，安東河回村，白川荻町，韓日比較研究

1.はじめに

(1) 背景と目的

急激な近代化によって多くの歴史的建造物及び歴史的景観が失 われつつあった 1960 年代以降, 韓国及び日本に打いてそれらを 保護する動きが広がった。その後現在に至るまで保護の対象は単 体の建造物から「景観」まで拡大した。西村はこれを,「点」か ら「線」へ，「線」から「面」への拡大としている ${ }^{1)}$ 。「歴史的景 観の保護」は言いかえれば，歴史的景観とされる「場所」に存在 するむののなかから「歴史的」景観の価值である保護対象を決定 し，そのほかの物についての方向性を定めるというしくみである。 本研究ではこのしくみ全体を「管理」とする ${ }^{2)}$ 。保護の対象であ ると同時にひとびとの「生活空間」でもある歴史的集落の「管理」 には「制度面での保証」とともに，様々な主体による実際の「管 理活動」の両者が必要である。歴史的集落の保護はすなわち，建 造物だけでない周囲の環境む含んだ歴史的な景観を保護対象とし ていると捉えることができるが，こうした歴史的集落の保護制度 は韓国，日本それぞれの国に扔いて進められてきた。本研究では 歴史的景観を守る「制度」である文化財保護制度があげられる文 化財を中心とした歴史的景観の管理がどのように機能しているの か，韓国と日本に㧍ける歴史的景観の管理に関わる制度や活動内 容についての比較から, 各々の特徵や差異を明らかにし, その背 景について考察することを目的とする。

（2）両国における歴史的景観保護に関する文化財保護制度の動向 韓国に抢ける歴史的集落の保護の始まりとして 1983 年に「楽 安村」が「史跡」に指定されたことがあげられる。1984 年には 河回村をはじめとする 3 箇所が，歴史的集落に打ける生活様式, 祭りなど無形の民俗学的な価值をむ包括する形で，「史跡」では なく, 従来からあった「民俗資料」という文化財のカテゴリーで 指定された。一方，「史跡」や「民俗資料」とは別の制度として， 1984 年に「伝統建造物保存法」が制定された。これは文化財以
外の建造物や地区の保護を目的とし，内部の改造を認めるなど， 従来の文化財保護制度に比べ緩やかな制度で，1988 年に「外岩 村」之「旺谷村」の 2 箇所が指定された。しかし，補償や指定を 受ける側の認識不足などによりその後の指定が続かず，うまく機 能しないまま1999 年には廃止されてしまった ${ }^{3)}$ 。その結果「伝 統的建造物」として指定されていた 2 集落はすべて「重要民俗資 料」として再指定され，「重要民俗資料」として指定されている 歴史的集落は合計 5 箇所となった。韓国では 1980 年代を中心之 した以上のような動きの後, 現在に至るまで文化財の保護対象之 しての歴史的集落は増加していない。その理由として，いわゆる 「凍結保存」を目標とした厳しい規制による管理が，実際に人々 の生活する集落を保護対象としにくいのではないかという点む指 摘されている ${ }^{4)}$ 。

一方，日本では全国的な歴史的集落保護のはじまりの時期であ $3^{55} 1970$ 年に平村相倉と上平村菅沼が「越中五箇山相倉集落」 「越中五箇山菅沼集落」としてそれぞれ史跡に指定された。これ は建造物を単体ではなく「群」として考え, その風土環境まであ 含めた地域を対称にするような趨勢に変わろうとした動きである とされている ${ }^{6)}$ 。1975 年には, 市民運動から始まり広がった動き に呼応する形で文化財保護制度に伝統的建造物群保存地区（以下 「伝建地区」）が導入された 的風致を形成している伝統的な建造物群で価值が高い」の伝建地 区の中でも「その価值が特に高いもの」と定義されている重要伝 統的建造物群保存地区（以下「重伝建地区」）は 1976 年白川村荻 町を含む 7 地区がまず選定され，その後増加を続け 2003 年 9 月 現在 61 地区となっている。伝建地区制度は多少の変化を認めつ つも「建造物群」を保護するというあので，そのあいまいさから 景観の变容など多くの問題点が指摘されている ${ }^{8)}$ 。

以上のことから, 韓国と日本の文化財保護制度ではいずれも当 初，一旦は「史跡」として文化財に指定されていた歴史的集落が

*東京大学大学院農学生命科学研究科 
韓国ではその後「伝統的建造物」をへて「民俗資料」として，日 本では「伝建地区」として制度的に保証されていることがわかる。 またそれぞれの制度はいわゆる「凍結保存」と変更の可能な緩や かな保護という違いが見られる。「制度」はさまざまな場所に適 用することが可能だが，その「制度」が実際の地域にどのように 具体的に適用され，「管理」の違いとなって現れているのか，韓 国之日本の事例において比較することは有効であると考えられる。

\section{(3) 研究対象選定及び研究方法}

本研究では現行の歴史的集落の管理に関わる制度である韓国の 「民俗資料」, 日本の「重伝健地区」に指定及び選定されている韓 国安東市河回村（以下，安東河回村）之岐阜県白川村荻町（以下， 白川荻町）を対象とする。対象地とした理由は以下の 4 点である。

(1)最屯早い時期に「民俗資料」及び「重伝建地区」として指定 及び選定された集落で，かつ史跡指定の影響がなく，現在までの 景観管理の変遷が把握できる。

(2)建造物だけでなく, 自然環境が集落の景観の重要な部分であ り，歴史的景観という側面から多様に検討できる。

(3)管理に関わる主体及び活動内容が多様で, 歴史的景観の管理 に関して比較が可能である。

(4)対象地区の面積, 集落の規模, 人口, 産業等がほほ類似して いるため, 韓国と日本の代表的事例として比較対象に適切である。 研究方法としては, 制度として文化財保護法と法以外の規制・基 準に関して，管理活動として管理に関わる主体及び活動内容を比

\begin{tabular}{|c|l|l|}
\hline 調查方法 & \multicolumn{1}{|c|}{ 安東市河回村 } & \multicolumn{1}{c|}{ 白川村荻町 } \\
\hline 文献調查 & 関連書籍、調查報告書、論文 & 関連書籍、調査報告書、論文 \\
\hline $\begin{array}{c}\text { 対象地 } \\
\text { 景観調查 }\end{array}$ & $2002.4,5,7,10$ 月 & 2002.8 月 \\
\hline $\begin{array}{c}\text { ヒアリング } \\
\text { 調査 }\end{array}$ & $\begin{array}{l}\text { ・儒教事業団の公務員 } \\
\text { ・河回村管理事務所の公務員 } \\
\text { ・河回村保存会の事務局長 } \\
\text { ・河回村公式Website 管理者 }\end{array}$ & $\begin{array}{l}\text { ・保存財団の総括主任 } \\
\text { ・関連研究者 }\end{array}$ \\
\hline
\end{tabular}

\section{表 -1 調査の対象及び内容}

較した。

調査は表一 1 に示すとおり, 報告書などの文献資料之, 現地に おける景観調查及びヒアリングから比較を行った。

安東河回村及び白川荻町の歴史的景観に関してはこれまでいく つかの研究でその問題点等が指摘されている。本研究の対象地に おける既往研究は比較研究, 事例研究にかかわらず実際の景観の フィジカルな変容を問題点としたもの ${ }^{9)}$, 变容の要因として「景 観管理 $\rfloor^{10)}$ あるいは「観光 $\rfloor^{11)}$ という事象をとりあげ，その因果関 係を明らかにしているものである。本研究ではこれらの既往研究 で指摘された問題点がそもそも文化財保護法を中心とした「景観 管理」の差に起因するのではないかという視点から韓国と日本の 事例を比較する。

\section{（4）対象地区の概要}

安東河回村は 1984 年文化財保護法重要民俗資料 122 号として 指定された。位置は慶尚北道安東市豊川面であり, 安東市儒教文 化圏の代表地である。建造物を中心に集落の全体の歴史的景観が

\section{表－２＼cjkstart文化財保護法からの差違}

\begin{tabular}{|c|c|c|}
\hline 項目 & 安東河回村 & 白川荻町 \\
\hline 法律 & 文化財保護法 & 文化財保護法 \\
\hline 主務官庁 & 文化観光部文化財庁 & 文部科学省文化庁 \\
\hline 文化財指定名称 & 重要民俗資料 & 重要伝統的建造物群保存地区 \\
\hline & $\begin{array}{l}\text { 韓国における文化財類型は有形文化財、無形文化財、記念物、民俗 } \\
\text { 凟料がある。安東河回村は民俗資料の類型で重要民俗资料に指定さ } \\
\text { れている。文化財保護法中には国家指定文化財として保護才る }\end{array}$ & $\begin{array}{l}\text { 日本における文化財類型は有形文化財、無形文化財、民俗文化財、 } \\
\text { 記念物、伝統的建造物群がある。白川荻町は伝統的建造物群の類型 } \\
\text { で重要伝統的建造物群保存地区に選定されている。 }\end{array}$ \\
\hline $\begin{array}{c}\text { 文化財指定類型の } \\
\text { 意味 } \\
\end{array}$ & $\begin{array}{l}\text { 民俗資料は衣食住、生業、信仰、年中行事等に関する衣服、器具、家 } \\
\text { 屋等で、国民生活の推移を理解するのに不可久なもの }\end{array}$ & $\begin{array}{l}\text { 伝統的建造物群は周囲の環境と一体をなして歴史的風致を形成して } \\
\text { いる伝統的建造物で価值の高いもの } \\
\end{array}$ \\
\hline $\begin{array}{l}\text { 同文化財に指定 } \\
\text { 及び選定された } \\
\text { 文化財の数 }\end{array}$ & 全部 951 件で民俗集落形は 5 件(2003.10) & 61 地区(2003.9) \\
\hline $\begin{array}{l}\text { 指定及び } \\
\text { 選定方法 }\end{array}$ & $\begin{array}{l}\text { 文化財庁の文化財委員会の審議により民俗資料の中から } \\
\text { 重要なものを重要民俗資料として指定 }\end{array}$ & $\begin{array}{l}\text { 伝統的建造物群保存地区は都市計画区域内においては条例で地区 } \\
\text { の保存のための法令の定めた基漼に従い必要な現状変更の規制を } \\
\text { 定める。都市計画区域以外は条例により、伝統的建造物群保存地区 } \\
\text { を定めることができる。伝統的建造物群保存地区の中、市町村の申出 } \\
\text { に基づき、区域の全部又は一部で価値が高いものを重要伝統的建 } \\
\text { 造物群保存地区として選定する }\end{array}$ \\
\hline 保護目的及び原則 & 原形維持を基本原則 & $\begin{array}{l}\text { 伝統的建造物群及びこれと一体をなしてその価值を形成している環境 } \\
\text { を保存 }\end{array}$ \\
\hline 具体的保護対象 & 文化財に指定された保護区域全体 & $\begin{array}{l}\text { 伝統的建造物(建築物、工作物)、伝統的建造物群と一体をなす環境 } \\
\text { (環境物件) }\end{array}$ \\
\hline $\begin{array}{l}\text { 保存管理活用の } \\
\text { 計画樹立義務付き }\end{array}$ & $\begin{array}{l}\text { 文化庁長は市道知事との協議により国家指定文化財の保存管理活用 } \\
\text { に関する基本計画の樹立ができる } \\
\end{array}$ & $\begin{array}{l}\text { 法では述べてないが、法を根拠にした条例を定めることが義務付けら } \\
\text { れている }\end{array}$ \\
\hline 管理者指定 & $\begin{array}{l}\text { 所有者不明とか所有者による管理が難しいと認める時、管理者を指定 } \\
\text { 寸る。河回村の場合、安東市が管理者である }\end{array}$ & ( \\
\hline $\begin{array}{l}\text { 現状変更の規制 } \\
\text { 要許可の行為 }\end{array}$ & $\begin{array}{l}\text { 現状変更行為 } \\
\text { ·国家指定文化財の修理·整備·復旧·除去等 } \\
\text { ·その他施設物の新築·増築·改築·移転、地形·地質の変更、水路·水質· } \\
\text { 水量の変更、騒音·振動·污染誘発、広告物等の設置·物の野積み等 } \\
\text { 保存に影響の恐れがある行為 } \\
\text { ·国家指定文化財の地域に影響を当たる上流の建築工事 } \\
\text { ·国家指定文化財500m 以内の地域の50m 以上騒音·振動· } \\
\text { 污染誘発、日照·景観に影響がある建物の新·増築 } \\
\text { その他周辺に影響の恐れがある行為 }\end{array}$ & $\begin{array}{l}\text { ·建造物等の新築、増築、改築、移転、又は除去 } \\
\text { ·建造物等の外観変更することになるも } \\
\text { ·宅地造成その他の土地形質変更 } \\
\text { ·木竹の伐採、土石の採取 } \\
\text { ·その他保存地区の現状を変更する行為 }\end{array}$ \\
\hline $\begin{array}{l}\text { 関連行政長の } \\
\text { 管理限界 }\end{array}$ & $\begin{array}{l}\text { 行政命令により文化財庁長又は地方自治団体長は保護·管理に必要 } \\
\text { と認められる時、管理者、所有者に行為禁止·施設設㯰及び除去の命 } \\
\text { 令ができる }\end{array}$ & $\begin{array}{l}\text { 文化庁長官又は都道府県の委員会は必要な指導や助言をすることが } \\
\text { できる }\end{array}$ \\
\hline 補助 & $\begin{array}{l}\text { ·文化財を管理する管理者の必要な経費 } \\
\text { ·行政命令から設置する措置の経費 } \\
\text { •その他管理·経費·保護·修理·記録の経費の全部あるいは一部を補助 }\end{array}$ & $\begin{array}{l}\text { 当該地区における保存のため市町村が行う措置についてその経費の } \\
\text { 一部を補助 }\end{array}$ \\
\hline 罰則 & 文化財損傷、無許可行為、行政命令違反等に関しては実刑又は罰金 & 法には述べてない \\
\hline
\end{tabular}


良好な状態で残っている。集落内にある国家指定文化財は国宝 2 件, 宝物 4 件, 重要無形文化財 1 件, 史跡 1 件, 集落自体を含め 重要民俗資料 10 件がある。この中, 12 件が建造物である。 白川荻町は合掌造りの家屋とその付属建物及び耕作地や周囲の自 然環境などで構成され, 歴史的及び景観的に価值が高いとして 1976 年に全国に先駆けて「重伝建地区」に選定され，1995 年に は「白川郷五箇山の合掌造り集落」という名称で世界遺産に登録 された22。

\section{2. 両集落における歴史的景観管理の特徵に関する比較 （1）両集落における文化財保護法に関する比較}

表- 2 は両集落に扔ける国の文化財保護法加らの歴史的集落の 管理手法について比較したものである。まず，文化財保護法でそ れぞれの集落の何を保護対象としているかについて比較する。安 東河回村は「重要民俗資料」で, 国家指定文化財として指定され ている。保護対象は建造物及び土地を含む地域の全体である。白 川荻町は「重伝建地区」で,「伝統的建造物」として建物を中心 とした「建築物」と鳥居や石垣などの「工作物」が指定され，伝 統的建造物群と一体をなす環境を構成する樹木などは「環境物件」 として指定されている。つまり, 安東河回村は面的な広がりを有 する集落全体が保護対象となっているのに対し, 白川荻町は面的 な広がりではなく,「伝統的建造物」,「環境物件」など個々の要 素を保護対象としている点が大きく異なっている。

次に文化財保護法による保護の方向性を比較する。安東河回村 は保護区域全体の原型維持が基本原則であり，白川荻町は保護対 象が「伝統的建造物」,「環境物件」として決定され, 結果的に 「地区の歴史的風致を維持する」とされている。

また, 法の定める管理の主体に関しては, 安東河回村は現状変 更の審議・許可者は国 (文化財委員会), 管理責任者は地方公共 団体 (安東市), 所有者（住民等）上明確に区分できるが，「伝建 地区」は国が指定できる重要文化財や国宝等の制度とは著しい違 いを持ち, 地方公共団体の主体性・自主性を尊重する制度である ため ${ }^{13)}$, 白川荻町では後述のように地方公共団体 (白川村) の保 存条例により管理されている。

賞罰の側面からみると, 安東河回村は規制に対する国, 地方公共 団体の補償, 違反に対する罰則が明確に定められている。白川荻 町は文化財保護法によって国が直接賞罰に関わる事はなく, 市町 村が行う管理活動に対する補助という点で安東河回村とは異なる。

（2）両集落における法以外の規制・基準の比較

両集落に扔ける歴史的景観管理に関わる法以外の条例, 計画, 基準，協定は表-3のとおりである。

\section{表 -3 歴史的景観管理に関わる法以外の規制・基準}

\begin{tabular}{|c|c|c|c|}
\hline & 主体 & & 名称 \\
\hline \multirow[b]{2}{*}{$\begin{array}{c}\text { 安東 } \\
\text { 河回村 }\end{array}$} & 安東市 & 条例 & 安東市河回村観覧料徵収条例 \\
\hline & $\begin{array}{c}\text { 儒教文化 } \\
\text { 開発事業団 }\end{array}$ & 計画 & 河回村入口観光地開発計画 \\
\hline \multirow{7}{*}{$\begin{array}{l}\text { 白川 } \\
\text { 荻町 }\end{array}$} & \multirow{4}{*}{$\begin{array}{l}\text { 地方 } \\
\text { 公共 } \\
\text { 団体 } \\
\text { (白川村) }\end{array}$} & 条例 & 白川村伝統的建造物群保存地区保存条例 \\
\hline & & 条例 & 白川村自然環境の確保に関する条例 \\
\hline & & 計画 & 白川村伝統的建造物群保存地区保存計画 \\
\hline & & 基準 & 白川村荻町伝統的建造物群保存地区保存基淮 \\
\hline & 財団※ & 計画 & 荻町総合振興計画 \\
\hline & \multirow{2}{*}{ 住民 } & 協定 & 荻町から看板をなくする運動 \\
\hline & & 協定 & 景観保存基準におけるガイドライン \\
\hline
\end{tabular}

※（財）世界遺産白川鄉合掌造り保存財団

安東河回村では文化財保護法に定められているように安東市は 管理責任者であり住民は所有者であるため, 保護制度は基本的に 文化財保護法のみである。そのため, 集落の歴史的景観管理に直 接に関連する法以外の条例・基準・カイドラインはない。間接的 に影響を与える条例は文化財保護法第 39 条によって定められた
「安東市河回村観覧料徴収条例」がある。この条例は観覽料徴収 に関する内容以外に観覽者の行為制限，住民所有以外の車両出入 り制限, 観覧料徵収に上る収入金の使用, 安東河回村管理事務 所 ${ }^{14)}$ の役割等, 文化財保護法の内容を補完し文化財として集落を 管理するために，必要な事項を定めている。

その他, 安東市の儒教文化開発事業団 ${ }^{15)}$ によって 1997 年から 2006 年までを事業期間として行われている「河回村入口観光地 開発計画」がある。この計画は安東河回村の観光地化による歴史 的景観の破壊を防ぎ，歴史的景観の管理及び観光による地域活性 化を同時に実現するため, 河回村入口から約 $1 \mathrm{~km}$ 離れた位置に 新たな観光拠点を開発するというものである。安東市はこの計画 が完了した後も引き続き, 観光関連活動は全部集落の外に誘導し, 安東河回村内は見学のみにして歴史的景観を管理するとされてい る。

「安東市河回村観覧料徴収条例」及び「河回村入口観光地開発 計画」は文化財保護法による重要民俗資料として管理される安東 河回村の原型維持を補助する役割をしていると考えられる。 白川荻町では文化財保護に関する業務を地方公共団体が主体的に 行うため, 歴史的景観管理に関わる具体的な規制は地方公共団体 の条例をむとに定められたものが中心になる。

「白川村伝統的建造物群保存地区保存条例」は文化財保護法第 83 条の 2 項の規制に基づき, 現状変更の規制, その他管理に関 する必要な措置を設置するために制定された。内容は「現状变更 の規制」,「許可基準」,「保存に関する補助」,「罰則」等がある。 これは地方公共団体が条例を定めて管理する形であり，文化財 保護法によって直接管理する安東河回村とは異なる。条例に基づ き策定された「白川村荻町伝統的建造物群保存地区保存基準」や 住民の協定である「荻町から看板をなくする運動」，「景観保存基 準に打けるガイドライン」等は条例による歴史的景観管理を補完 するものである。これらの基準及びガイドライン等は建造物を中 心として舗装や看板などの景観を構成する要素に関して具体的な 数值や材料などを規定・誘導する内容となっている。

\section{（3）両集落における管理に関わる主体及び活動内容の比較}

ここでは両集落の管理活動の主体とその活動内容を比較する。 表一 4 は管理に関わる主体と各主体の活動内容である。活動内容 は歴史的景観管理のための実際に行う行為之補助金支給による支 援との 2 つに分けて示した。

安東河回村に打ける管理活動の主体としては安東市儒教文化開 発事業団及び安東河回村管理事務所（以下「管理事務所」）があ る。特に安東市の直轄部署として安東河回村に常住している管理 事務所は具体的な管理事務を担当している。管理事務所は集落に 常駐しながら不法現状変更の取り締まり, 保存状態の点検をし, 修理復旧等の現状变更の必要性を判断し, 安東市儒教文化開発事 業団に報告する。儒教文化開発事業団は現状変更申請に関する 書類を作成して文化財庁の文化財委員会の審議を受け, 文化財庁 長から許可をむらう仕組みである。安東河回村では他の国家指定 文化財之同じように「審議・許可」「管理事務」の 2 段階となっ ており，保護を中心した管理をしているといえる。一方，白川荻 町では管理事務は主に財団及び住民の組織である白川村荻町の自 然環境を守る会（以下「守る会」）が中心となっており，守る会 に打いて現状变更に関する住民の申請を協議して決定する。決定 の困難な事項については白川村教育委員会及び有識者, 村の各地 区の代表等で構成されている白川村伝統的建造物群保存地区保存 審議会の審議を受ける。白川荻町では「審議・許可」「協議」「管 理事務」の 3 段階で, 安東河回村と異なる「協議」のための仕組 みがある。これは白川荻町の歴史的景観管理が法にもとづく上位 下達式の規制とは別の仕組みを持っているともいえる。

補助金では, 補修, 調査・啓蒙に関しては双方の集落でみられ 
表 -4 管理に関わる主体と書く主体の活動内

\begin{tabular}{|c|c|c|c|c|c|c|c|c|c|c|}
\hline & \multirow[b]{2}{*}{ 主体名 } & \multirow[b]{2}{*}{ 活動内容 } & \multicolumn{4}{|c|}{ 行為 } & \multicolumn{4}{|c|}{ 補助金 } \\
\hline & & & \begin{tabular}{l|l} 
許 \\
可
\end{tabular} & $\begin{array}{l}\text { 審 } \\
\text { 議 }\end{array}$ & $\begin{array}{l}\text { 協 } \\
\text { 議 }\end{array}$ & $\begin{array}{l}\text { 管 } \\
\text { 理 } \\
\text { 事 } \\
\text { 務 }\end{array}$ & $\begin{array}{l}\text { 補 } \\
\text { 修 }\end{array}$ & 修 & \begin{tabular}{|l} 
住 \\
補 \\
助
\end{tabular} & \begin{tabular}{|l} 
\\
調 \\
查 \\
晵 \\
蒙 \\
\end{tabular} \\
\hline \multirow{5}{*}{$\begin{array}{l}\text { 安 } \\
\text { 東 } \\
\text { 河 } \\
\text { 回 } \\
\text { 村 }\end{array}$} & 文化財庁·文化財庁長（国） & 現状変更の許可 & $\mathrm{O}$ & & & & 0 & & O & $\mathrm{O}$ \\
\hline & 文化財庁文化財委員会（国） & 現状変更の許可審議 & & 0 & & & & & & \\
\hline & 安東市儒教文化開発事業団（市） & $\begin{array}{l}\text { 観光計画及び事業、観光資源発掘調查管理業務、 } \\
\text { 開発補償業務、文化財関連の住民請願処理、文化 } \\
\text { 財復旧修理計画、文化財委員会に現状変更の許可 } \\
\text { 申請、保存会の管理、国費補助金管理、不法現状 } \\
\text { 変更の取り締まり、文化財及びその周辺環境整備 }\end{array}$ & & & & $\mathrm{O}$ & $\mathrm{O}$ & & $\bigcirc$ & $\mathrm{O}$ \\
\hline & 安東河回村管理事務所（市） & \begin{tabular}{|l|} 
不法現状変更の取り締まり、保存状態点検, 文化 \\
財及びその周辺環境整備、文化財紹介及び伝承
\end{tabular} & & & & O & & & & \\
\hline & 安東河回村保存会（民） & \begin{tabular}{|l|} 
住民共益保護 \\
\end{tabular} & & & & & & & O & \\
\hline \multirow{5}{*}{$\begin{array}{c}\text { 白 } \\
\text { 川 } \\
\text { 荻 } \\
\text { 町 }\end{array}$} & 文化庁（国） & 補助金の補修 & & & & & 0 & & & \\
\hline & 白川村·白川村教育委員会 （村） & $\begin{array}{l}\text { まちづくり、法的文化財管理事業、 } \\
\text { 保存会の現状変更申請事業補助 }\end{array}$ & $\mathrm{O}$ & & & & O & 0 & & $\mathrm{O}$ \\
\hline & 白川村伝統的建造物群保存地区保存審議会（村） & 現状変更申請の審議、調査協議 & & $\mathrm{O}$ & & & & & & \\
\hline & 世界遗産白川鄉合掌造り保存財団（財団） & $\begin{array}{l}\text { 修理事業、修景事業、住民保存活動の支援、調査 } \\
\text { 普及事業、継続事業 }\end{array}$ & & & & 0 & O & 0 & & $\mathrm{O}$ \\
\hline & 白川村荻町の自然環境を守る会（民） & 現状変更申請の事并審査、啓蒙事業 & & & O & & & $\mathrm{O}$ & & $\mathrm{O}$ \\
\hline
\end{tabular}

成引いては景観にも 大きく反映している ことなど，日本にも 西欧にあない特徵が あり，保護すべき歴 史的景観と住民の生 活空間との分離を複 雑なあのにしており, そのあり方の検討む 大きな課題である。 また一方，白川荻町 の場合には，歴史的 建造物と環境物件を 保護することで歴史 的景観保護を目指し ているが，保護対象 である建造物や物件

るが，安東河回村が規制による補償として住民補助をしているの に対し，白川荻町は修景による景観管理に対して補助金を支給し ている。

\section{3. 考察}

本研究では韓国と日本に扔ける文化財保護制度を中心に安東河 回村之白川荻町の歴史的景観管理に関する制度や活動内容につい て各々の特徴の差異を明らかにした。韓国の安東河回村では, 集 落及び周辺農地を含んだ面的な広がりを単体の保護対象として位 置づけ，他の文化財保護と同様の管理の考え方を歴史的景観の管 理に適用している。一方，日本の白川荻町では「伝統的建造物」 「環境物件」といった景観を構成する要素を直接の保護対象とし, 要素間の「景観的調和」による「歴史的風致の維持」と, 保護を 基本とした歴史的景観之住民生活の近代化との両立を目指してい るという点が大きく異なっている。つまり, 安東河回村では「保 護志向の強い歴史的景観管理」となっており，白川荻町では 「調和志向の強い景観管理」を目指していると言えょう。

それゆえ, 安東河回村は景観まで拡大された文化財保護のため の規制によって直接影響を受ける住民に対する補償が重要であり， 白川荻町は「調和」を図るのための住民側の「協議」及び「非伝 統的景観に関する修景」等が主な管理手法になっている。

両国の文化財保護制度ではいずれも文化財に関する概念が「景 観」まで広がり, 景観を構成する要素群である歴史的集落という 管理対象を一旦は「史跡」として管理し始めた。しかし，このよ うな管理対象は「住民の生活空間」を含む場合が少なくないため, 既存の文化財のように「審議・許可」「管理事務」という２段階 で管理することは難しい。そこで, 白川荻町のような「調和指向 型の管理」が生まれるようになったのは自然の流れであると考え られる。しかし韓国では緩やかな制度であった「伝統建造物保存 法」を経てむしろより厳しく集落と周辺農地をむ含んだ面的な広 がりを「民俗資料」として歴史的景観を管理することになった。 韓国の場合は, 民俗学や歴史学上の価值を優先させ, 歴史的集落 の景観や生活様式を，そのまま民俗資料として保護しようとする 国の強い意志をうかがうことができる。当初，こうした国を中心 とした保護指向の強い歴史的景観管理は, 歴史的集落の「血縁」 抄よび「地縁」を基盤とする住民サイドの伝統を護ろうとする意 識が強いことが支えになっていたとも考えられる。しかしながら 現在では生活様式の大きな変化を背景に, 国, 住民ともにその意 識が弱まってきており, 住民生活に対する配慮が重要な課題となっ ている。また, 歴史的集落の保護之住民生活の現代化を両立させ るにしてす, 韓国の場合「班常」16)制度に関わる階層性が空間構
をはじめとする要素相互の関係に関する検討が十分に行われてい ないため, 景観を構成する要素の保護にとどまってしまい，修景 之称される管理活動の過程で, 要素およびその相互関係によって 形成される景観的特性を消失してしまう恐れがあり，歴史的景観 の形骸化及び真正性の消失等に関する批判が少なくない。要素の みならず要素相互の関係をについて調査し，景観特性を保護対象 とする景観管理のあり方を検討していくことが課題であると考え ている。

\section{補注及び引用文献}

1）西村幸夫（1997）：環境保全と景観創造：鹿島出版社, 154-156

2) 高口らは「自治体を含めた地域全体が一中略一価值を明確にし, 再生 産し高めていくためのシステム」を「景観管理」としているが（高口 愛・西山徳明 $(2000)$ ：伝統的景観管理とその变遷：日本建築学会計 画系論文集 No.538，133-140）本研究では主体として国をあ含めた保 護のためのしくみを「管理」とする。

3 ) Kang, Dongjin and Dongsik Choi (2002) The guideline for the Extension and Establishment of historic District's Concept in Kor ea. : K P A 37(4) 41-58

4 ) Hong, Junseop (1998)：韓国の町並み保存の課題に関する研究; 町 並み保存制度に㧍ける日韓の比較を中心として：日本観光研究学会全 国大会研究発表論文集 No.13, 149-156

5 ）前掲 1) 150-152

6 ）近代建築（1973）：歴史的環境の保存 11 ; 保存の危機-五箇山：近代建 築 $27(11), 83-86$

7 ）黑田乃生・小野良平（2003）白川村研究の系譜にみる文化財としての 集落景観保全に求ける問題点：ランドスケープ研究 66(5)，665-668

8 ) 前揭 1) $171-175$

9）西山德明・三村浩史 (1995)：伝統的建造物群保存地区における景観管 理計画に関する研究:日本建築学会計画系論文集 No.474, 133-141 等

10）黑田乃生・下村彰男・小野良平・能谷洋一 (2001)：白川村荻町伝統 的建造物群保存地区に抄ける集落景観の特徵之その保全に関する研究： ランドスケープ研究 64(5), 759-764 等

11）黑田乃生・下村彰男（2001）：世界遺産登録後の白川村荻町に㧍ける 観光の現状とその方向性に関する考察 : 第 36 回日本都市計画学会学 術論文集, 253-258, 荒井崇浩・十代田朗 (2002)：観光地化に伴亏農山村 伝統集落の空間变容及び住民生活への影響に関する研究一富山県五箇 山相倉を事例として：第 37 回日本都市計画学会学術論文集 949-954 等

12）（財）世界遺産白川郷合掌造り保存財団（2001）：白川郷合掌造り集落 の景観；白川村荻町伝統的建造物群保存地区の景観に関する調查報告 書

13）荻谷勇雅（2001）：伝統的建造物群保存地区制度について; 歴史的集 落・町並みの保存-重要伝統的建造物群保存地区ガイドブック：文化 庁, $230 \mathrm{p}$

14）安東河回村の管理のため，安東市の直轄部署として作られた事務所て ある。安東河回村の入口に位置。安東市行政規則集による補職は文化 財管理員 1 人, 行政事務職 3 人, 機能職 6 人である。

15）安東市は慶尚北道儒教文化圈の観光育成化計画により，既存の文化財 担当部署之新設した文化財を生かして地域観光に活用する開発担当部 署を統合し儒教文化開発事業団とした。

16）過去の韓国における身分で，両班之常民之をあわせて称する。韓国の 歷史的集落では今も「班常」による階層性が空間的に反映されている。 